\title{
Pembuatan Portal Website Sekolah SMA Negeri 1 Sungailiat Sebagai Media Informasi
}

\author{
Riki Afriansyah*1, Sari Mubaroh², Indah Riezky Pratiwi \\ 1,2,3Politeknik Manufaktur Negeri Bangka Belitung \\ 1,2Program Studi Teknologi Rekayasa Perangkat Lunak, Jurusan Teknik Elektro dan Informatika, \\ Politeknik Manufaktur Negeri Bangka Belitung \\ ${ }^{3}$ Program Studi Teknik Perancangan Mekanik, Jurusan Teknik Mesin, Politeknik Manufaktur Negeri \\ Bangka Belitung \\ *e-mail: riki.afrian@gmail.com ${ }^{1}$
}

\begin{abstract}
The existence of a school website is very important to disseminate information needed for schools, teachers, students and the community. With the website, information can be easily managed by the school. For example, important announcement information, the school operator can input the information through the website portal so that the public can read the information effectively and efficiently without having to come to school. In addition, the public can communicate with school operators through the chat feature and download the required documents via the web. Another feature is the photo album and video activities carried out by the school as a promotional media as well as the features that are connected to social networking services namely Instagram. The results of the final interview this activity was obtained that this website provides many benefits for the community as well as ease in managing information systems by operator.
\end{abstract}

Keywords: Website, Information, Promotion, Information Systems

\begin{abstract}
Abstrak
Keberadaan website sekolah sangatlah penting untuk menyebarkan informasi yang dibutuhkan bagi sekolah, guru, siswa dan masyarakat. Dengan adanya website maka informasi dapat dikelola dengan mudah oleh sekolah. Misalnya informasi pengumuman penting maka operator sekolah tinggal memasukkan informasi tersebut melalui portal website maka masyarakat dapat membaca informasi tersebut secara efektif dan efisien tanpa harus datang ke sekolah. Selain itu juga masyarakat dapat berkomunikasi dengan operator sekolah melalui fitur chat serta mengunduh dokumen yang dibutuhkan melalui web. Fitur lainnya adanya album foto dan video kegiatan yang dilakukan oleh sekolah sebagai media promosi serta adanya fitur yang terhubung dengan layanan jejaring sosial yaitu instagram. Dari hasil wawancara akhir kegiatan ini diperoleh bahwa website ini memberikan banyak manfaat bagi masyarakat serta kemudahan dalam pengelolaan sistem informasi bagi operator.
\end{abstract}

Kata kunci: Website, Informasi, Promosi, Sistem Informasi

\section{PENDAHULUAN}

SMA Negeri 1 Sungailiat merupakan salah satu sekolah favorit di Kabupaten Bangka. Selain itu juga banyak prestasi secara akademik maupun non akademik yang diperoleh oleh siswa-siswi maupun guru-guru yang ada di SMA Negeri 1 Sungailiat namun belum terdokumentasi dan terpublikasi melalui portal website sekolah. Prestasi yang diraih oleh siswasiswi maupun guru di SMA Negeri 1 Sungailiat sangat perlu dipublikasikan melalui website agar menjadi daya tarik masyarakat untuk melakukan kerja sama atau sebagai media promosi untuk meningkatkan citra dan kredibilitas sekolah. Website sekolah sebagai sarana untuk promosi sekolah yang lebih efektif dan menjangkau lebih luas (Anwar, Purnomo, \& Hartono, 2017). Dengan website sekolah maka penyajian informasi akan lebih luas dan waktu penyajiannya dapat kapan saja (Syarifudin, 2019).

Penerapan sistem informasi dapat meningkatkan kinerja dan daya saing (Maslim, Adithama, \& Nugroho, 2020). Sistem informasi dapat meningkatkan kualitas pendidikan yang prima kepada masyarakat (Darmansyah \& Suhendro, 2020). Masyarakat yang ingin mengetahui informasi yang ada di SMA Negeri 1 Sungailiat seperti informasi pendaftaran siswa baru maka 
masyarakat harus datang ke sekolah. tentunya hal ini tidak efisien dari sisi waktu. Website sebagai media yang digunakan untuk menggantikan aktifitas yang bersifat manual dan menghabiskan banyak waktu menjadi aktifitas komputerisasi (Lubis, Khairani, \& Wulan, 2020). Kegiatan pelatihan atau event yang ada di SMA Negeri 1 Sungailiat cukup banyak seperti perlombaan cerdas cermat antara SMA, pelatihan untuk pembuatan kurikulum bagi guru dan sebagainya namun hanya sebagian masyarakat yang mengetahui informasi tersebut.

Adanya portal website sekolah diharapkan dapat membantu SMA Negeri 1 Sungailiat dalam mengelola dan memberikan informasi yang bermanfaat bagi sekolah dan masyarakat. website sekolah terdapat beberapa manfaat antara lain turut hadir dalam memberikan kontenkonten positif bagi publik untuk mewujudkan internet sehat (Mushlihudin, Setiadi, \& Pujiyono, 2019). Dengan adanya sistem informasi dapat memberikan kemudahan bagi skolah, guru maupun warga sekolah dalam mengakses informasi tentang sekolah tersebut (Wahyuni, Putra, \& Wadisman, 2020). Dengan adanya website maka dapat membantu admin dalam melakukan pengontrolan data dan informasi yang dibutuhkan (Christian, Hesinto, \& Agustina, 2018).

Dengan website sekolah SMA Negeri 1 sungailiat maka masyarakat dengan mudah mengakses informasi seperti profil sekolah yang terdiri dari visi misi, struktur organisasi, penghargaan yang diperoleh, ekstrakurikuler, lomba-lomba yang diikuti, event dan lain sebagainya. Website dapat menyajikan informasi berupa seputar kegiatan kampus yang akan diadakan, maupun yang telah diadakan (Salmun, 2019). Selain itu penggunaan social media yang terhubung dengan website sangat diperlukan untuk mempercepat promosi sekolah. Strategi promosi lewat media sosial dapat dijadikan benchmark (Setyowardhani \& Susanti, 2020).

\section{METODE}

Adapun metode pelaksanaanya dapat dilihat pada alur diagram di bawah ini.

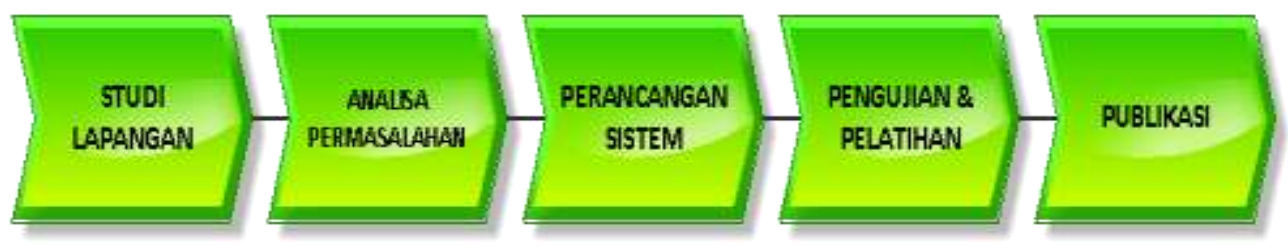

Gambar 1. Alur Pelaksanaan

Penjelasan dari alur di atas sebagai berikut:

\section{a. Studi Lapangan}

Pada tahapan ini melakukan kunjungan ke SMA Negeri 1 Sungailiat. Mengidentifikasi permasalahan mengenai proses promosi dan penyampaian informasi kepada masyarakat dengan cara berdiskusi dengan pihak sekolah.

\section{b. Analisa Permasalahan}

Dari studi lapangan diperoleh solusi yang akan digunakan dalam pembuatan website sekolah sesuai dengan kebutuhan yang diharapkan.

\section{c. Perancangan Sistem}

Pada tahapan ini yaitu membangun website berbasis website dengan framework codeigniter dan database mysql. 
d. Pengujian dan Pelatihan

Setelah website sekolah dibangun maka website tersebut dilakukan pengujian terlebih dahulu. website sekolah sudah siap digunakan maka tahapan selanjutnya akan diadakan pelatihan bagi operator untuk menggunakan dan mengelola informasi yang akan dipublikasikan.

e. Publikasi

Publikasi hasil dari pengabdian masyarakat akan diterbitkan pada jurnal pengabdian masyarakat.

\section{HASIL DAN PEMBAHASAN}

Adapun kegiatan pengabdian masyarakat dalam pembuatan portal website sekolah SMA Negeri 1 Sungailiat sebagai media informasi sebagai berikut:

a. Studi Lapangan dan Analisa Permasalahan: pada kegiatan ini melakukan kunjungan ke SMA Negeri 1 Sungailiat kemudian melakukan wawancara dan diskusi dengan kepala sekolah, guru dan operator mengenai portal website sekolah yang akan dibangun.

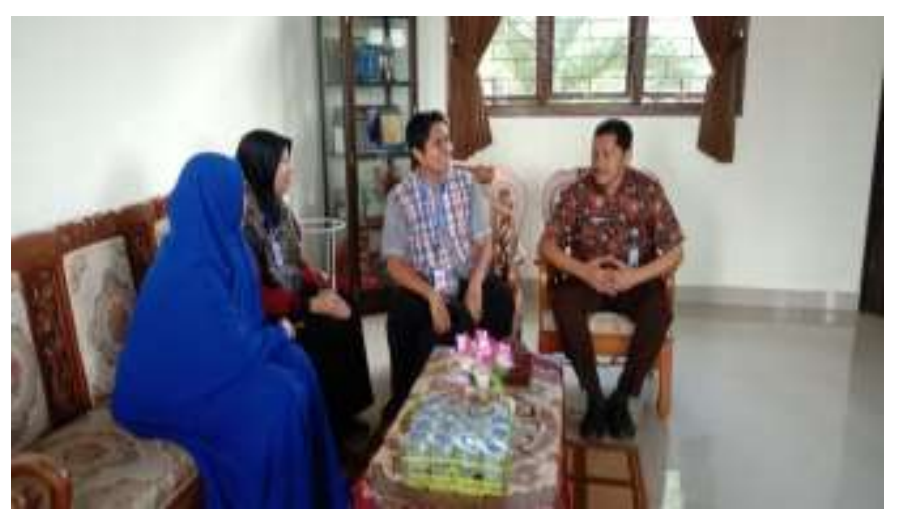

Gambar 2. Diskusi Dengan Pihak SMA Negeri 1 Sungailiat

Dari hasil diskusi tersebut diperoleh fitur-fitur yang harus ada pada portal website SMA Negeri 1 Sungailiat. Adapun fitur-fitur yang dibutuhkan pada portal website sebagai berikut:

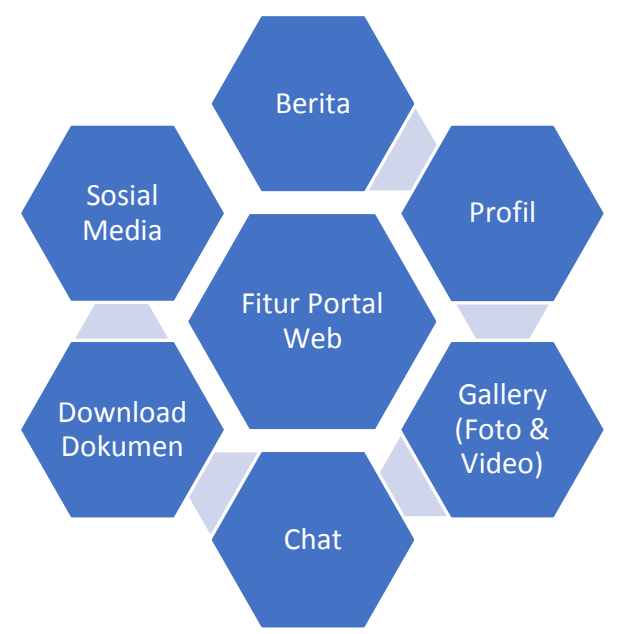

Gambar 3. Fitur Portal Website Sekolah 
b. Perancangan Sistem: Sistem portal website dibagi menjadi dua tampilan yaitu: tampilan admin untuk mengelola informasi yang hanya bisa dikelola oleh operator atau admin sekolah dan tampilan publik di mana tampilan ini dapat dilihat oleh semua orang.

b.1 Tampilan Menu Admin: menu ini hanya dikelola oleh admin atau operator sekolah

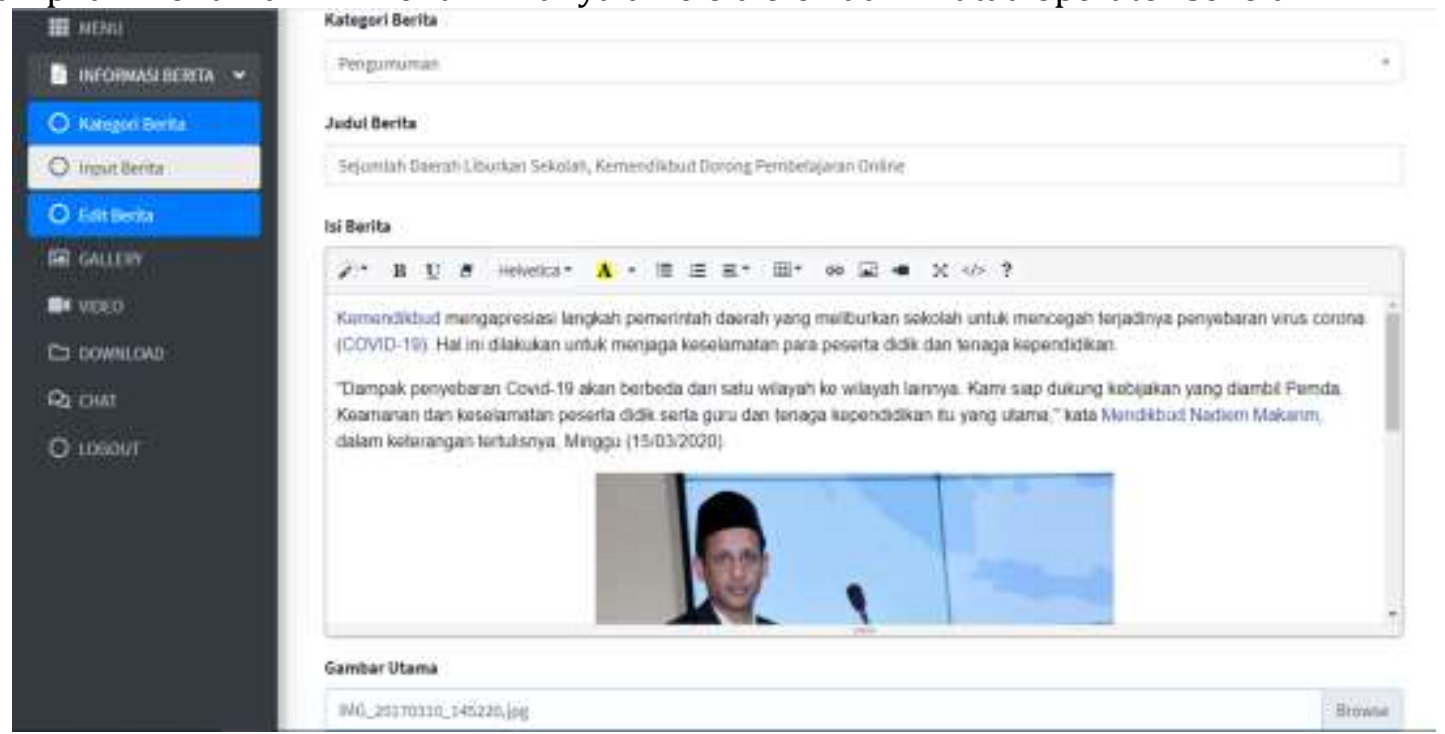

Gambar 4. Menu admin dalam mengelola berita

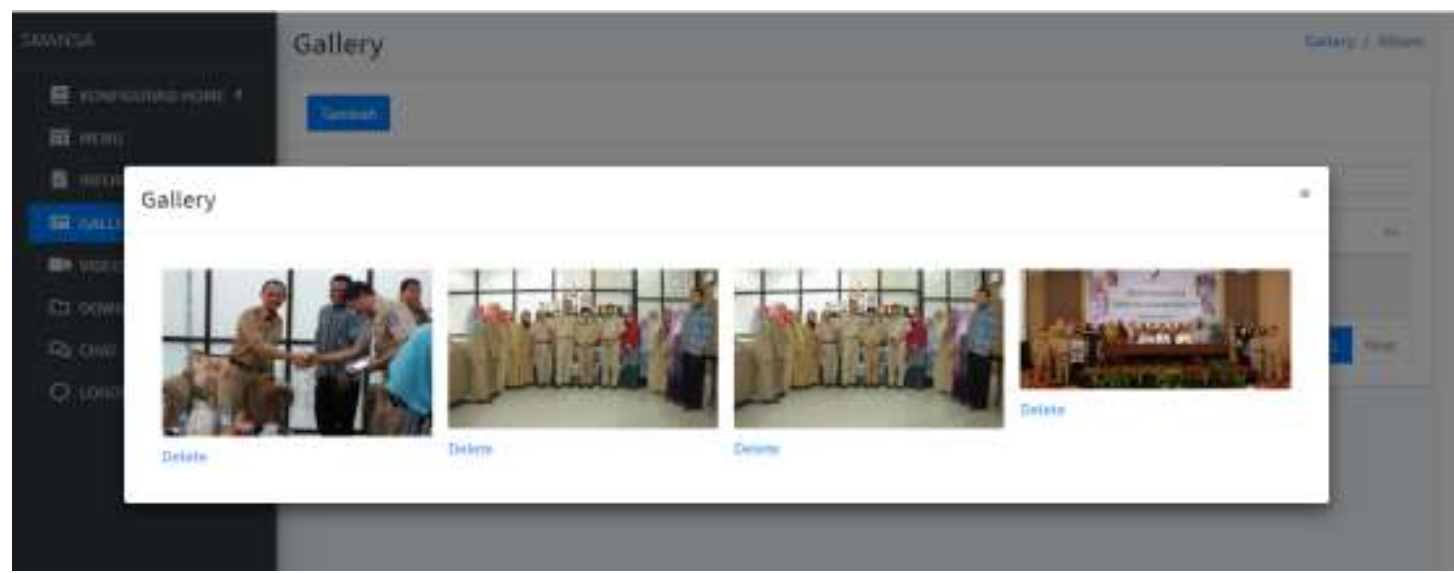

Gambar 5. Menu admin dalam mengelola foto

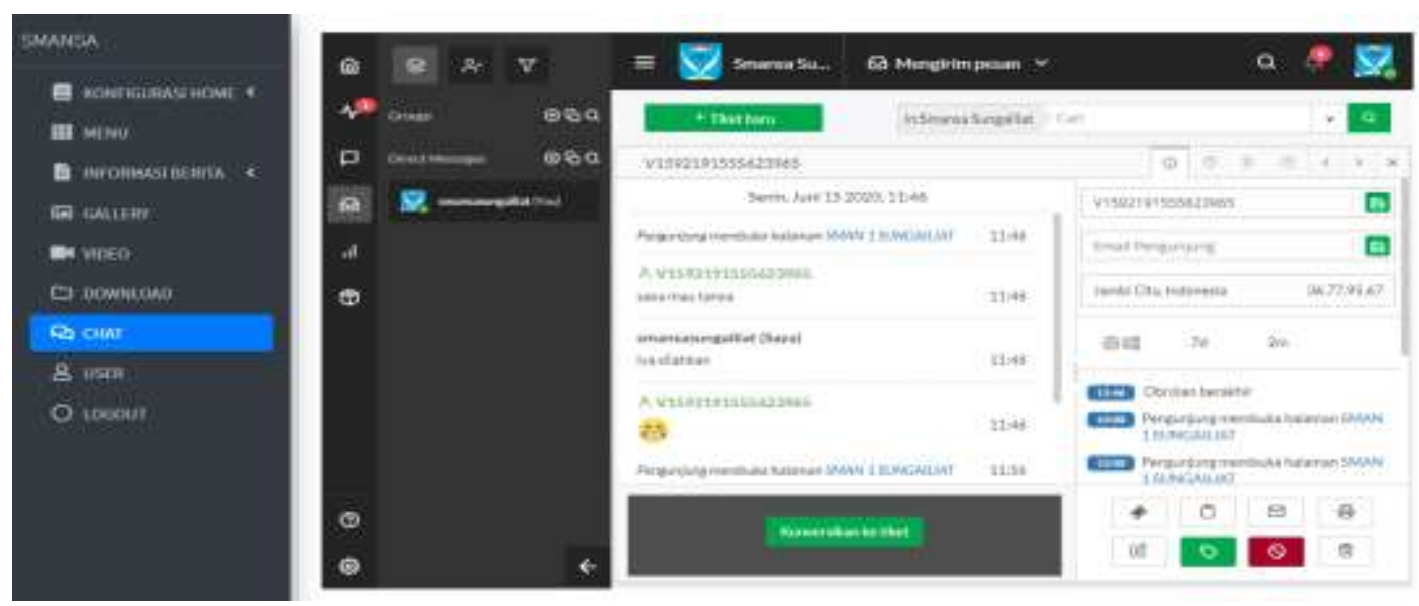

Gambar 6. Menu admin dalam mengelola chat (Obrolan) 
b.2 Tampilan Publik: menu ini dapat diakses oleh semua orang

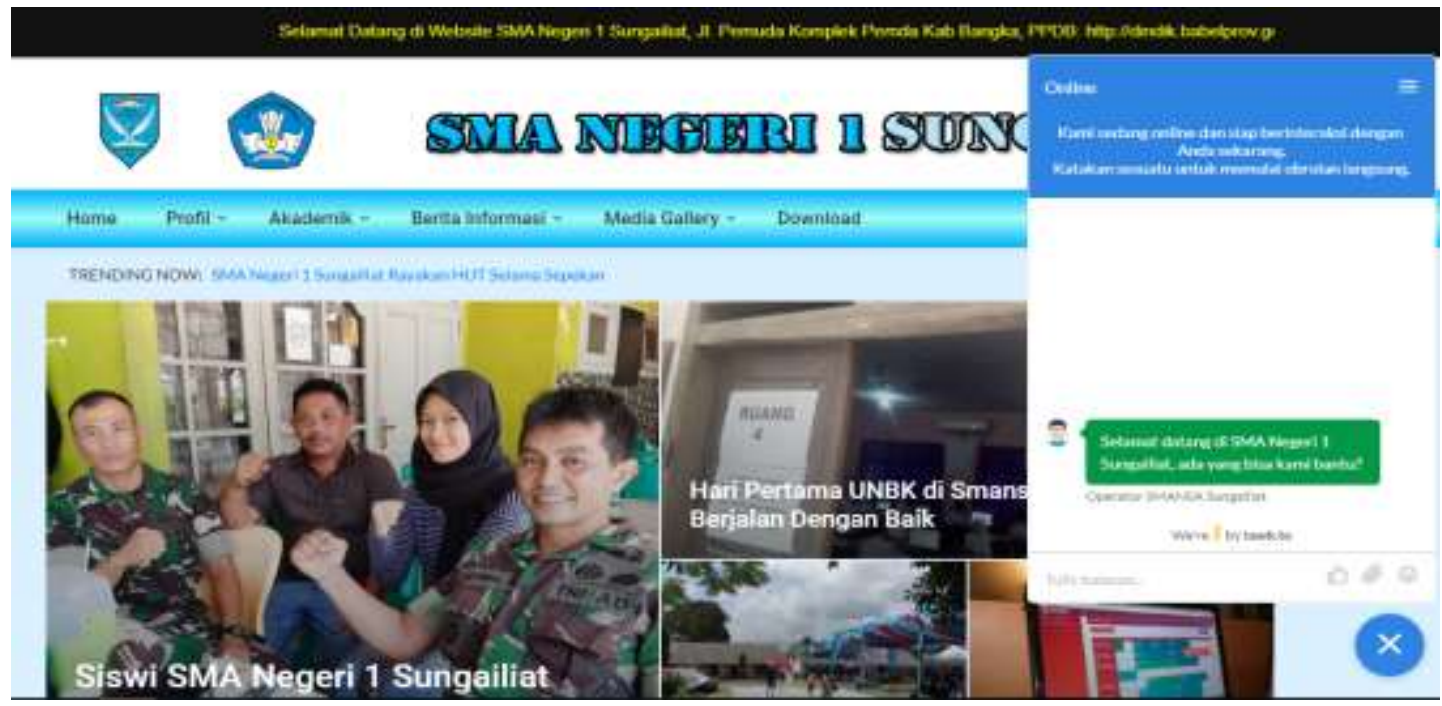

Gambar 7 Tampilan Publik Menu Chat

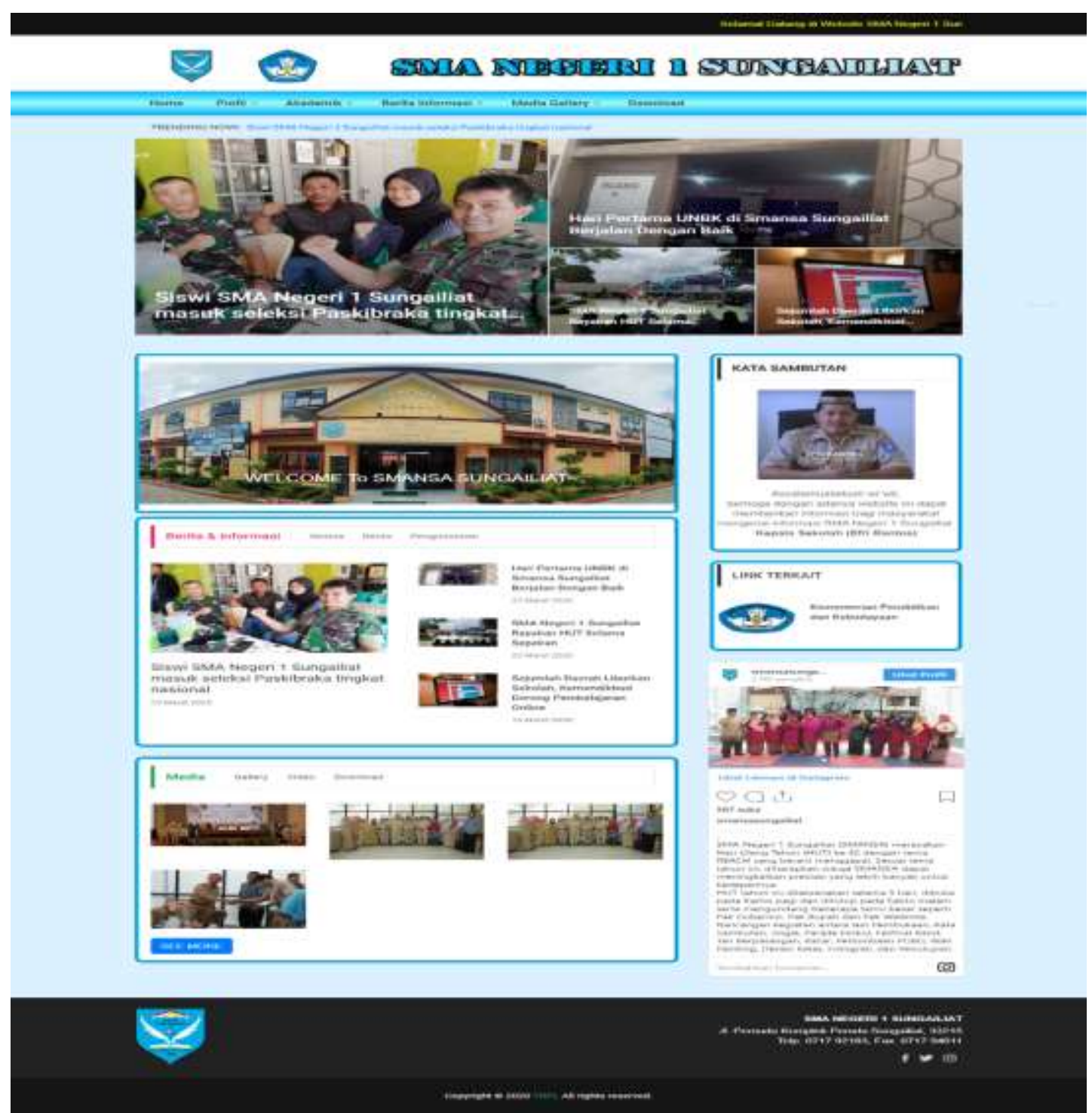

Gambar 8 Tampilan Publik Menu Home 
c. Pengujian dan Pelatihan: Setelah website dibangun sesuai dengan fitur-fitur yang diinginkan maka tahapan selanjutnya melakukan pengujian dan pelatihan bagi operator yang akan mengelola informasi sekolah. Ada dua operator sekolah yang akan mengelola portal website SMA Negeri 1 Sungailiat. Adapun fitur pada admin yaitu: Konfigurasi home, menu, informasi berita, gallery, video, download, chat dan user.

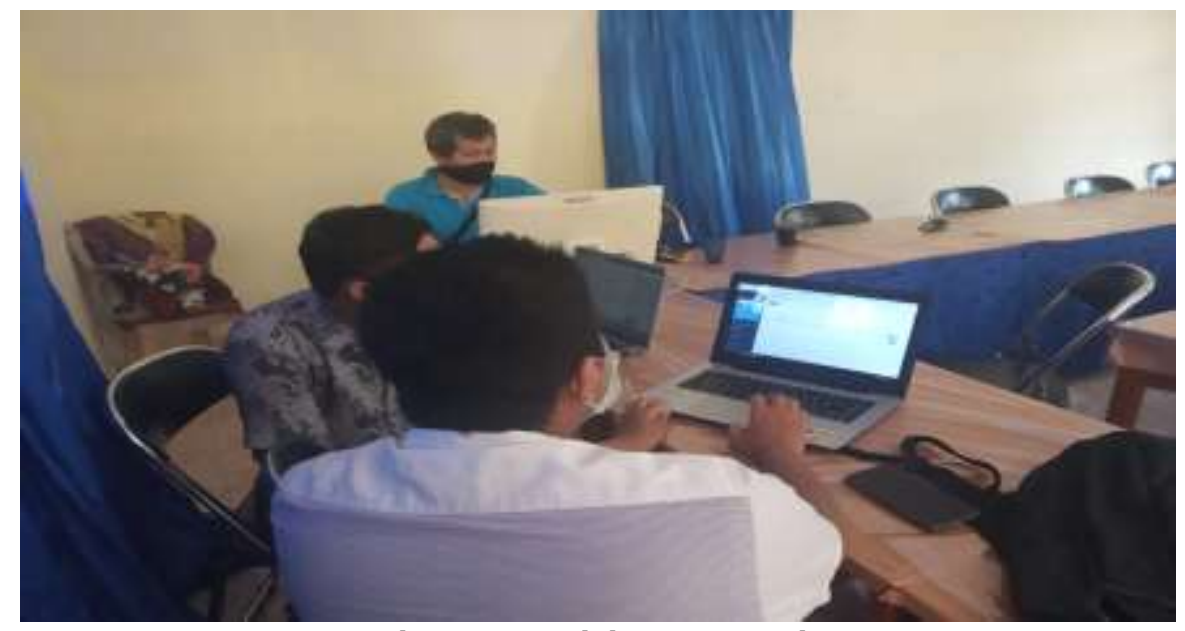

Gambar 9. Pengelolaan menu admin

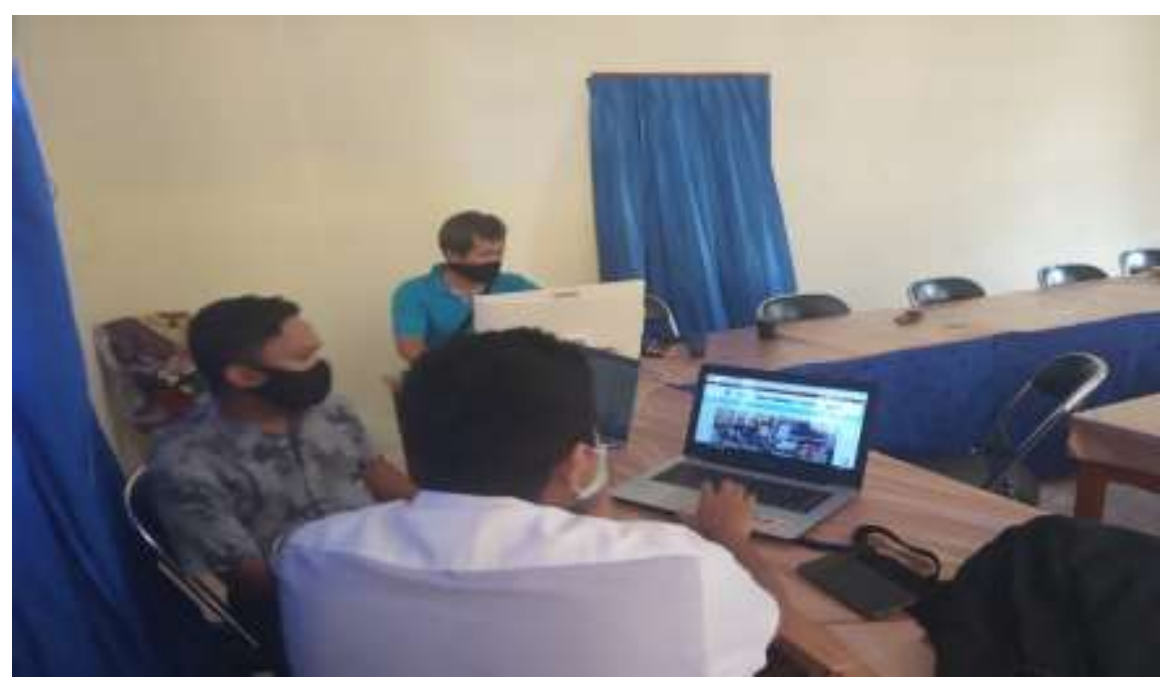

Gambar 10. Penjelasan antara menu admin dengan menu tampilan publik

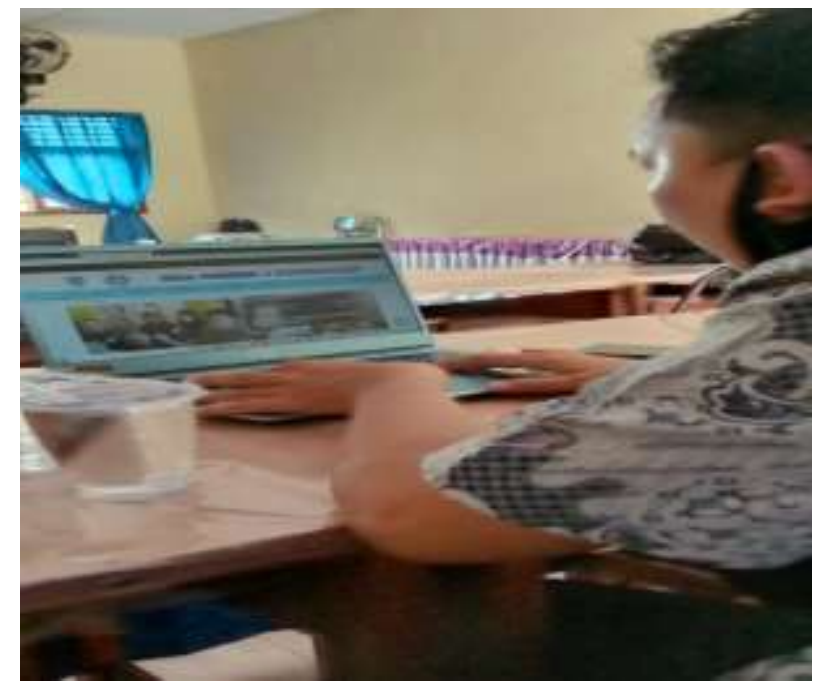

Gambar 11. Operator mencoba melakukan pemasukkan dan pembaharuan informasi 
Setelah selesai kegiatan pelatihan maka dilakukan evaluasi terhadap kegiatan pengabdian masyarakat ini dengan melakukan wawancara pada pihak sekolah yang terdiri dari kepala sekolah, guru-guru dan dua operator SMA Negeri 1 Sungailiat bahwa dengan adanya portal website ini sangat membantu pihak sekolah dalam menyebarkan informasi serta kemudahan bagi masyarakat untuk berkomunikasi dan memperoleh informasi tanpa harus datang ke SMA Negeri 1 Sungailiat sehinggal lebih efisien dari sisi waktu.

\section{KESIMPULAN}

Dari hasil pembahasan di atas dapat diperoleh simpulan bahwa dengan adanya website sekolah ini mempermudah pihak sekolah dalam menyebarkan informasi penting seperti pengumuman, kegiatan sekolah dan informasi lainnya. Selain itu juga dengan adanya website ini sebagai media promosi sekolah kepada masyarakat. Masyrakat dapat secara langsung berkomunikasi dengan pihak operator sekolah melalui web ini dengan adanya fitur chat serta mengunggah dokumen formulir yang dibutuhkan misalnya untuk keperluan pendaftaran siswa baru. Fitur-fitur yang ada pada website ini dibangun sesuai dengan kebutuhan dari pihak sekolah..

\section{DAFTAR PUSTAKA}

Anwar, F., Yunianto, M., Purnomo, A., \& Hartono, R. (2017). Upaya Peningkatan Kualitas Sekolah Melalui Pembuatan dan Pengelolaan Website Sekolah Studi Kasus di Sekolah Muhammadiyah se Kecamatan Polokarto Kabupaten Sukoharjo. WASANA NYATA, 1(3), 23-28.

Christian, A., Hesinto, S., \& Agustina, A. (2018). Rancang Bangun Website Sekolah Dengan Menggunakan Framework Bootstrap (Studi Kasus SMP Negeri 6 Prabumulih). Jurnal Sisfokom (Sistem Informasi dan Komputer), 7(1), 22-27.

Darmansah, D., \& Suhendro, Z. (2020). Sistem Informasi Sekolah Pada Sd Negeri 21 Sungai Geringging Kabupaten Padang Pariaman Berbasis Web. MATRIK: Jurnal Manajemen, Teknik Informatika dan Rekayasa Komputer, 19(2), 235-245.

Lubis, Y. F. A., Khairani, M., \& Wulan, N. (2020). PKM: Pembangunan Website Sekolah dan Penerimaan Siswa Baru Pada Sekolah Nur Nur Azizi Berbasis Content Management System (CMS). TRIDARMA: Pengabdian Kepada Masyarakat (PkM), 3(1, Mei), 117-121.

Maslim, M., Adithama, S. P., \& Nugroho, A. H. T. (2020). Pembangunan Sistem Informasi Penjualan Pada Usaha Mikro, Kecil, Dan Menengah (Studi Kasus: Pahala Fotokopi dan Digital Printing). Dinamisia: Jurnal Pengabdian Kepada Masyarakat, 4(1).

Mushlihudin, M., Setiadi, T., \& Pujiyono, W. (2019). Pendampingan Pengelolaan Website Sekolah Muhammadiyah di Kota Yogyakarta. Jurnal Pemberdayaan: Publikasi Hasil Pengabdian Kepada Masyarakat, 2(3), 413-420.

Salamun, S. (2018). Rancang Bangun Website Sekolah Tinggi Ekonomi Islam (Stei) Iqra Annisa Sebagai Wadah Penyebaran Informasi. Rabit: Jurnal Teknologi dan Sistem Informasi Univrab, 3(1), 29-34.

Setyowardhani, H., \& Susanti, H. (2019). Optimalisasi Media Sosial Sebagai Alat Promosi Untuk Desa Wisata Lebakmuncang. Dinamisia: Jurnal Pengabdian Kepada Masyarakat, 3.

Syarifudin, G. (2019). Website Sekolah Sebagai Optimalisasi Penyampaian Informasi pada SMK AlMadani Pontianak. SINDIMAS, 1(1), 265-269.

Wahyuni, S., Putra, R. R., \& Wadisman, C. (2020). Pengembangan Sekolah SMA/SMK Yapim Taruna Marelan Dengan Sistem Informasi Akademik Berbasis Web. INTECOMS: Journal of Information Technology and Computer Science, 3(1), 52-59. 